Article

\title{
Performance Characteristics of a PEM Fuel Cell with Parallel Flow Channels at Different Cathode Relative Humidity Levels
}

\author{
Pil Hyong Lee and Sang Soon Hwang* \\ Department of Mechanical Engineering, University of Incheon, Songdo Dong, Yeonsu-Ku, Incheon, \\ Korea; E-Mail: meman80@incehon.ac.kr \\ * Author to whom correspondence should be addressed; E-Mail: hwang@incheon.ac.kr;
} Tel.: +82-32-770-8417; Fax +82-32-770-8410.

Received: 26 August 2009; in revised form: 4 November 2009 / Accepted: 5 November 2009 / Published: 17 November 2009

\begin{abstract}
In fuel cells flow configuration and operating conditions such as cell temperature, humidity at each electrode and stoichiometric number are very crucial for improving performance. Too many flow channels could enhance the performance but result in high parasite loss. Therefore a trade-off between pressure drop and efficiency of a fuel cell should be considered for optimum design. This work focused on numerical simulation of the effects of operating conditions, especially cathode humidity, with simple micro parallel flow channels. It is known that the humidity at the cathode flow channel becomes very important for enhancing the ion conductivity of polymer membrane because fully humidified condition was normally set at anode. To investigate the effect of humidity on the performance of a fuel cell, in this study humidification was set to $100 \%$ at the anode flow channel and was changed by $0-100 \%$ at the cathode flow channel. Results showed that the maximum power density could be obtained under $60 \%$ humidified condition at the cathode where oxygen concentration was moderately high while maintaining high ion conductivity at a membrane.
\end{abstract}

Keywords: humidity; micro parallel flow channels; fuel cell; numerical simulation 


\section{Introduction}

The PEM (Proton Exchange Membrane) Fuel Cell is an electrochemical device that directly converts chemical energy into electrical energy. Its features, such as high power density, simple construction, and fast startup make it suitable for applications in automotive and domestic appliances [1-3]. A typical schematic of a Proton Exchange Membrane Fuel Cell (PEMFC) is shown in Figure 1(a) The cell is a sandwich of two graphite bipolar plates with micro flow channels and separated by MEA (Membrane Electrode Assembly) which consists of a membrane and two electrode with dispersed Pt catalyst. The gas diffusion layer (GDL) is porous to supply reactants to the electrodes in the unexposed areas of the micro flow channels [4].

Figure 1. Schematics of a fuel cell assembly displaying different essential components of the system (a) and micro serpentine bipolar flow plate (b).

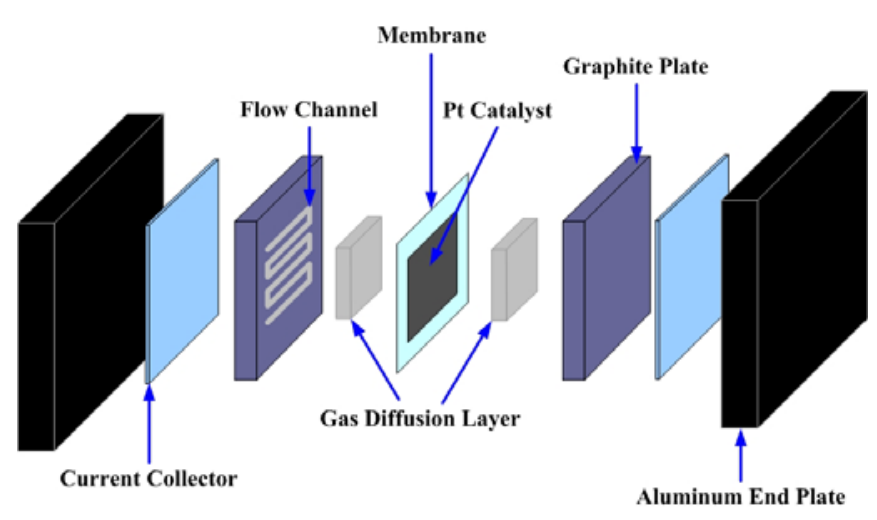

(a)

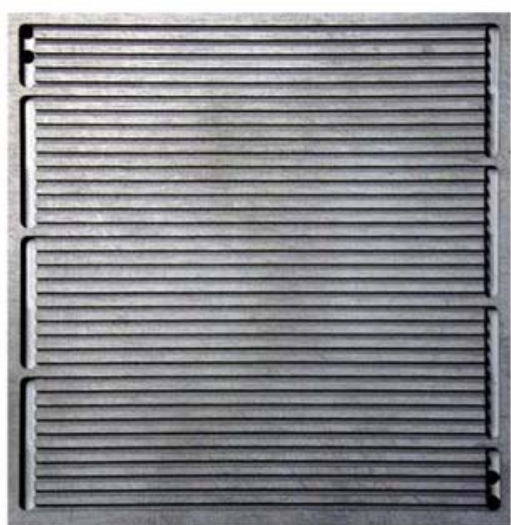

(b)

As shown Figure 1(b), typical serpentine bipolar flow plates in fuel cells contain many micro flow channels to distribute the reactant gas flow over the catalytic reactive surface. The shape, size and pattern of micro flow channels are known to greatly affect fuel cell performance.

Selection of operating conditions for PEMFC with parallel, serpentine, interdigitated flow channels are very important to improve the performance of fuel cells. Generally the operating pressure and temperature, equivalence ratio are known to be key elements to increase its performance and their effects on performance were studied by many researchers. However little study on the effects of humidity in air and hydrogen has been carried out until now. Wang et al. [5] reported that the reactant relative humidity and the flow field design significantly affect cell performance. For the same operating conditions and reactant relative humidity, the interdigitated design has better cell performance than the parallel design. With a constant anode relative humidity $=100 \%$, for lower operating voltages, a lower cathode relative humidity reduces cathode flooding and improves cell performance, while for higher operating voltages, a higher cathode relative humidity maintains the membrane hydration to give better cell performance. Ohsaka et al. [6] showed that symmetric relative humidity has different impact, depending on the cell temperature. While at relative humidity of 35\% the cell showed considerable performance at a cell temperature $=70{ }^{\circ} \mathrm{C}$, it was not so at a cell temperature of $90{ }^{\circ} \mathrm{C}$. At cell temperature of $70^{\circ} \mathrm{C}$, the cell potential increases with relative humidity at 
lower and medium current densities, but decreases with relative humidity at higher currents. In this study, we attempt to develop a fully three dimensional computational model for PEM fuel cell which can deal with both anode and cathode micro parallel flow channels. To investigate the effect of humidity on performance of fuel cell, humidification condition is set to $100 \%$ at the anode flow channel and is changed by $0-100 \%$ at the cathode flow channel. The commercial program FLUENT (Version 6.3) was modified using UDF (User-Defined Functions) in order to simulate electrochemical reactionz and related phenomena that occurred in a PEMFC with micro parallel flow channel. [7-13] The distribution of water and oxygen concentration along the micro parallel flow channel and gas diffusion layer, water transport though membrane, and membrane ion conductivity were investigated and analyzed.

\section{Numerical Models}

\subsection{Model Assumptions}

Governing equations for calculating the fully three dimensional flow channel are expressed under following assumptions:

(1) The gas mixture is incompressible, ideal fluid;

(2) The flow in the flow channel is laminar (Reynolds number $<900$ at anode and cathode relative humidity $100 \%)$;

(3) Isothermal condition;

(4) Butler-Volmer kinetics for electrochemical reaction rate.

\subsection{Governing Equations}

(1) Mass conservation equation:

$$
\nabla \cdot(\varepsilon \rho \vec{u})=S_{m}
$$

where $\varepsilon$ is the porosity of the porous media, which is equal to unit for the gas channels, $\rho$ the density, and $\bar{u}$ the intrinsic fluid velocity vector, $\varepsilon \bar{u}$, reflects the superficial velocity in the porous media. $S_{m}$ denotes source terms corresponding to the consumption of hydrogen and oxygen in the anode and cathode, and the production of water in the cathode:

$$
\begin{aligned}
& S_{m}=S_{H_{2}}+S_{a w}: \text { Anode Side } \\
& S_{m}=S_{O_{2}}+S_{a w}: \text { Cathode Side }
\end{aligned}
$$

(2) Momentum conservation equation

The fluid flow in the fuel cell can be described by the general equation as:

$$
\nabla(\varepsilon \rho \vec{u} \vec{u})=-\varepsilon \nabla p+\nabla(\varepsilon \mu \nabla \vec{u})+S_{u}
$$

where $\rho$ denotes the pressure, $\mu$ the effective viscous coefficient. Because the fluid flowing in the channels, gas diffusion layers and catalyst layer membrane is different, $\mu$ stand, for gas viscous 
coefficient for gas mixture in the channel and gas diffusion layer, and liquid viscous coefficient for liquid in the catalyst layer and membrane. Furthermore, mass-weighted mixing law gives viscosity of the gaseous mixture. The source terms in the momentum equations are added based on the Darcy's law, representing an extra drag force in the equation as follows:

$$
S_{u x}=-\frac{\mu u}{\beta_{x}}, S_{u y}=-\frac{\mu v}{\beta_{y}}, S_{u z}=-\frac{\mu w}{\beta_{z}}
$$

where $\beta_{x}, \beta_{y}$ and $\beta_{z}$ are the permeability in the $\mathrm{x}, \mathrm{y}, \mathrm{z}$ direction and $\mathrm{u}, \mathrm{v}$ and $\mathrm{w}$ are the velocities in $\mathrm{x}, \mathrm{y}$ and $\mathrm{z}$ directions respectively.

(3) Species conservation equation

The species conservation equation for the gas mixture is:

$$
\nabla\left(\varepsilon \vec{u} C_{k}\right)=\nabla\left(D_{k}^{e f f} \nabla C_{k}\right)+S_{k}
$$

Here, $k$ denotes chemical species that include hydrogen, oxygen, nitrogen and water. $D_{k}^{\text {eff }}$ is the effective diffusion coefficient. Source term $S_{k}$ denotes:

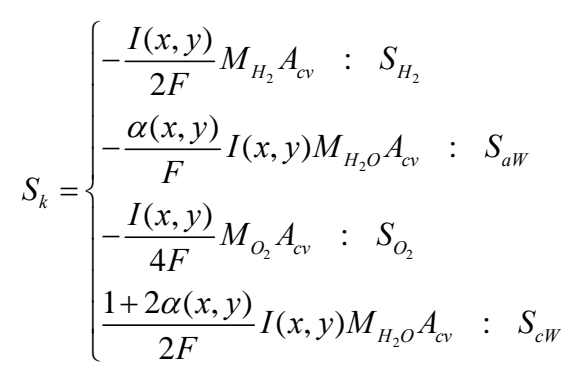

where $M_{\mathrm{H}_{2}}, M_{\mathrm{H}_{2} \mathrm{O}}$ and $M_{\mathrm{O}_{2}}$ are the molecular weight of hydrogen, water and oxygen.

\subsection{Water Transport Equation}

Water management is a critical issue for the performance of a proton electrolyte membrane fuel cell. The transport phenomena of water can be described as follows: the water molecules are transported through the polymer electrolyte membrane by the protons and this process is called electro-osmotic drag. In addition to the molecular diffusion and electro-osmotic drag, water is generated in the cathode catalyst layer due to electro chemical reaction.

(1) Electro-osmotic drag flux

Electro-osmotic water flux through the membrane can be calculated from the proton flux through the membrane, given by the specified current density and Faraday's law:

$$
J_{\mathrm{H}_{2} \mathrm{O}}=2 \times n_{d} \frac{I(x, y)}{2 \mathrm{~F}}: \text { Electro-osmotic drag flux }
$$

where $n_{d}$ is Electro-osmotic drag coefficient which depends on water activity as follows:

$$
n_{d}=0.0029 \lambda^{2}+0.05 \lambda-3.4 \times 10^{-19}
$$


where $\lambda$ represents water contend of the membrane described as:

$$
\begin{aligned}
& \lambda=0.043+17.81 a_{K}-39.85 a_{K}^{2}+36.0 a_{K}^{3}, 0<a_{K}<1 ; \\
& \lambda=14+1.4\left(a_{K}-1\right), 1<a_{K} \leq 3
\end{aligned}
$$

where $a_{K}$, water activity, is expressed as:

$$
a_{K}=\frac{X_{w, K} P(x, y)}{P_{w, K}^{s a t}}, K=\text { Anode or Cathode }
$$

where $X_{w, K}, P^{s a t}$ are water mole fraction and saturation pressure at each electrode respectively:

$$
\log _{10} P^{\text {sat }}=-2.1794+0.02953 T-9.1837 \times 10^{-5} T^{2}+1.4454 \times 10^{-7} T^{3}
$$

(2) Back diffusion flux

The water formation at the cathode results in a gradient in the water content between the cathode side and anode side of the membrane. For PEMFC, this gradient causes a water flux back to the anode side which is superimposed to the electro-osmotic flux. This back diffusion is expressed as following water flux:

$$
J_{H_{2} O, \text { back diffusion }}=-\frac{\rho_{m, d r y}}{M_{m, d r y}} \times D_{w} \times \frac{d \lambda}{d y}: \text { Back diffusion flux }
$$

where $\rho_{m, d r y}$ is the dry density of electrolyte, $M_{m, d r y}$ is the electrolyte equivalent weight, and $z$ is the direction through the membrane thickness.

$D_{w}$ is water diffusion coefficient which is strongly dependent on water content as follows:

$$
\begin{aligned}
& D_{w}=D_{\lambda} \exp \left(2416\left(\frac{1}{303}-\frac{1}{T_{\text {cell }}}\right)\right) ; D_{\lambda}=10^{-10}, \lambda<2 \\
& D_{\lambda}=10^{-10}(1+2(\lambda-2)), 2 \leq \lambda \leq 3 ; \\
& D_{\lambda}=10^{-10}(3-1.67(\lambda-3)), 3<\lambda<4.5 ; \\
& D_{\lambda}=1.25 \times 10^{10}, \lambda \geq 4.5
\end{aligned}
$$

(3) Current density and membrane ion Conductivity

$I(\mathrm{x}, \mathrm{y}, \mathrm{z})$ is current density generated by electrochemical reaction, which can be expressed as:

$$
I(x, y, z)=\frac{\sigma_{m}(x, y, z)}{t_{m}}\left\{V_{o c}-V_{c e l l}-\eta(x, y, z)\right\}
$$

where $\sigma_{m}(\mathrm{x}, \mathrm{y}, \mathrm{z})$ indicates the ion conductivity of membrane expressed as:

$$
\sigma_{m}(x, y, z)=\left(0.00514 \frac{M_{m, d r y}}{\rho_{m, d r y}} C_{w, a}(x, y, z)-0.00326\right) \exp \left(1268\left(\frac{1}{303}-\frac{1}{T_{s}}\right)\right) \times 10^{2}
$$




\subsection{Numerical Simulation Model}

A schematic of the micro parallel flow channel with GDL and catalyst layer is shown in Figure 2. Cross sectional area at inlet of micro parallel flow channel is $762 \times 762(\mu \mathrm{m})$ and its length is $40(\mathrm{~mm})$. Thickness of the gas diffusion layer and catalyst layer is set to $254(\mu \mathrm{m})$ and $28.7(\mu \mathrm{m})$, respectively.

Figure 2. Schematic of the micro parallel flow channel structure.

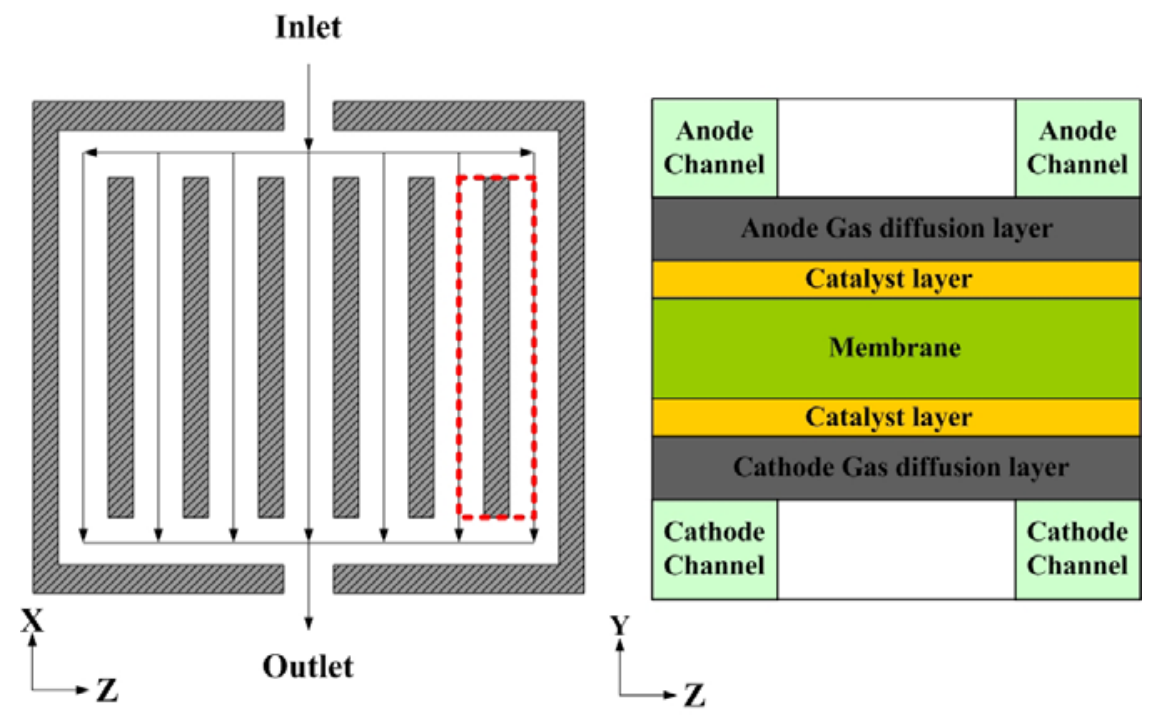

Figure 3 show the computational mesh structure for the micro parallel flow channel. Orthogonal non-uniform grids are employed for computational the domain. The micro parallel flow channels of anode and cathode are divided into $40 \times 50 \times 24$ (total mesh number is 48,000). The numerical results using a mesh size twice as large as the present mesh size were almost same, so we used the present mesh size to save calculation run time.

Figure 3. Computational grids for the micro parallel flow channels.

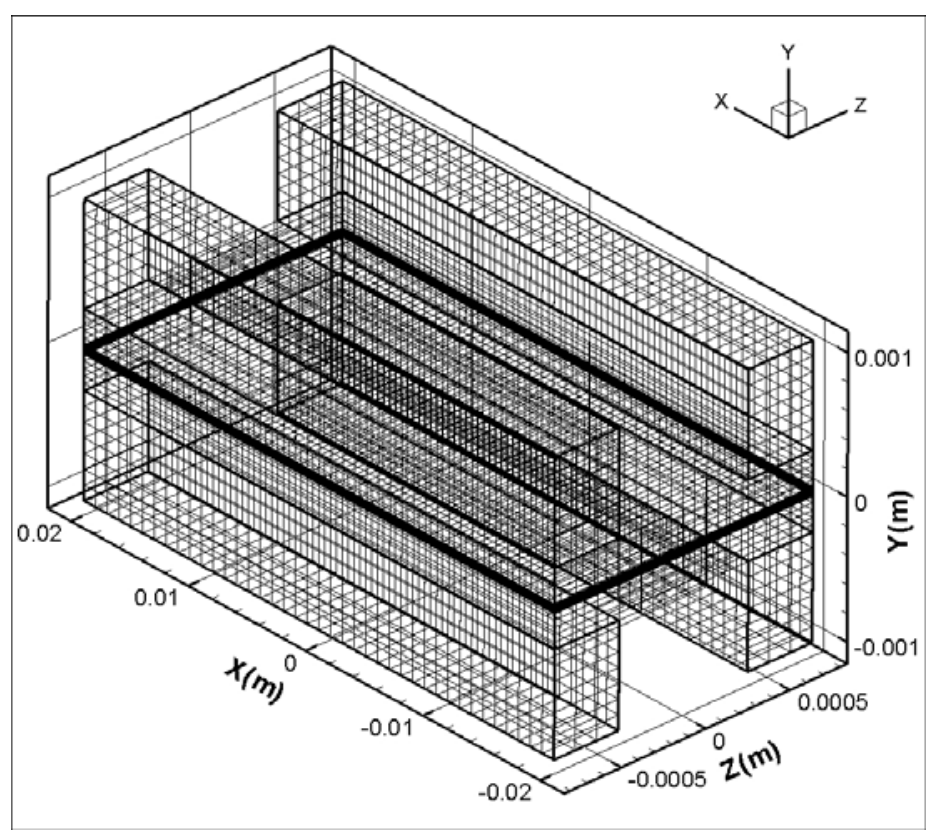


At the inlets, the fluid is supposed to display laminar flow into the micro parallel flow channel at known velocity because $\mathrm{Re} \#$ at anode and cathode is 900 under $100 \%$ relative humidity conditions and the atmospheric pressure is set at the outlets. Table 1 provides the physical parameters necessary for numerical calculation.

Table 1. Physical parameters.

\begin{tabular}{cccc}
\hline Description & Value & Description & Value \\
\hline Channel length $(\mathrm{mm})(\mathrm{mm})$ & 40 & Anode, Cathode side pressure & 1 \\
Channel width $(\mu \mathrm{m})$ & 762 & Cell temperature $(\mathrm{K})$ & 353.15 \\
Channel height $(\mu \mathrm{m})$ & 762 & Anode stoichiometric number & 1.5 \\
GDL thickness $(\mu \mathrm{m})$ & 254 & Cathode stoichiometric number & 2.0 \\
GDL porosity & 0.7 & $\mathrm{O}_{2} / \mathrm{N}_{2}$ ratio & $0.21 / 0.79$ \\
Wet Membrane thickness $(\mu \mathrm{m})$ & 230 & Anode side Humidification $(\%)$ & 100 \\
Catalyst layer thickness $(\mu \mathrm{m})$ & 28.7 & Cathode side Humidification $(\%)$ & $0-100$ \\
\hline \multicolumn{5}{c}{ Experimental MEA Parameters } \\
\hline Membrane & Nafion 117 & Pt catalyst loading $\left(\mathrm{mg} / \mathrm{cm}^{2}\right)$ & 0.4 \\
\hline
\end{tabular}

\section{Discussions}

For a validation check of the numerical simulation model used in this study, the performance data were compared with the experimental data of a fuel cell with a parallel flow channel obtained under the same conditions as shown in Figure 4. The computed polarization curve is in favorable agreement with the experimental polarization curve [14,15].

Figure 4. Comparison of experimental and computed polarization curves.

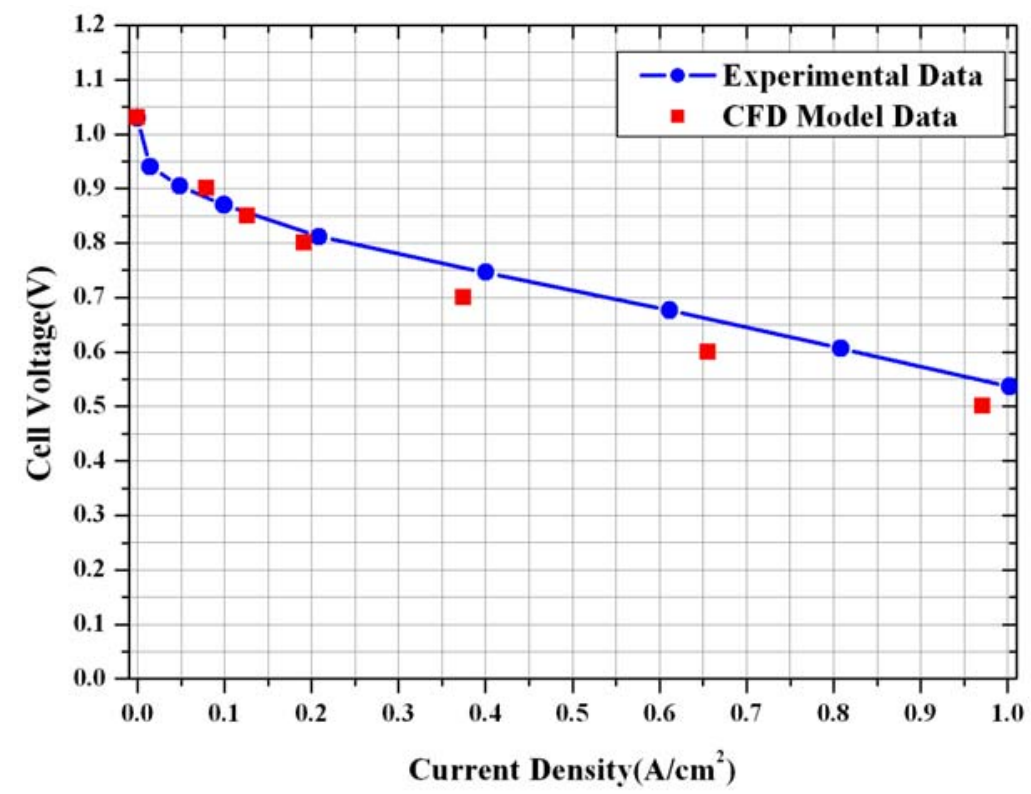


Figure 5 presents the current density(i)-voltage(V) polarization curve for PEM fuel cell with micro parallel flow channels under conditions of $100 \%$ anode side relative humidity and $0 \%$ cathode side relative humidity. The current density increased with decreasing cell voltage. The voltage for the maximum power density at $0.5 \mathrm{~V}$ was found to be the optimal operation condition for the PEM fuel cell $[14,15]$.

Figure 5. Current density(i)-Voltage(V) and power density curves.

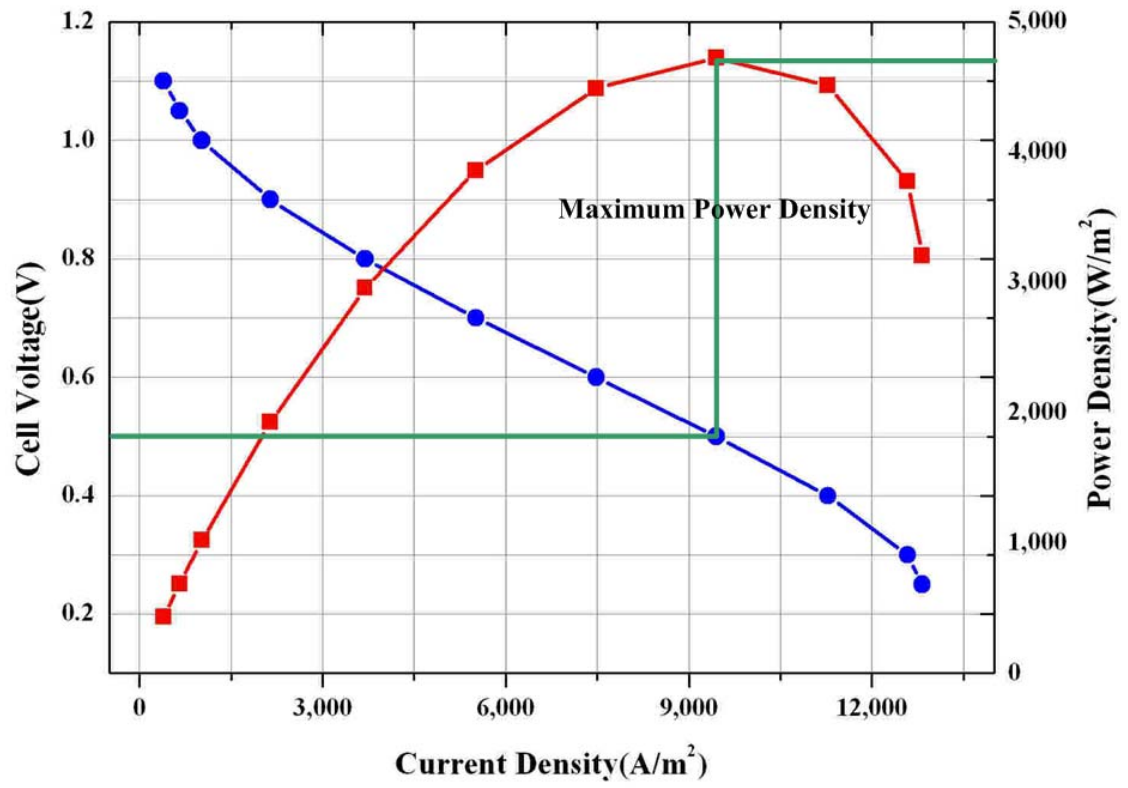

Using this numerical simulation model and the conditions listed in Table 1, calculations were carried out to examine performance of fuel cell at operating cell voltage $0.5 \mathrm{~V}$. Figure 6 shows the water concentration at the centerline surface of the channel at $0.5 \mathrm{~V}$ and under conditions of $0-100 \%$ cathode side relative humidity. The water concentration at the anode side shows almost the same contour, regardless of the value of relative humidity at the cathode, because $100 \%$ humidified hydrogen was supplied to the anode side. At the cathode side, the water concentration increased along the flow direction because water was generated from the electrochemical reaction and water was transported by electro-osmotic drag as oxygen flowed along the axis. The water concentration became the highest at the inlet of the flow channel when 100\% cathode humidity was supplied because water concentration tends to increase at the inlet of the flow channel as the relative humidity of cathode increases.

The oxygen concentration at cathode flow channel is a very important parameter to determine better performance of fuel cell. Figure 7 depicts the distribution of oxygen concentration along the centerline surface of channel. A high distribution of oxygen concentration was found at the inlet of the flow channel when the humidity of oxygen at the cathode side was low. The oxygen concentration at the cathode decreased along the flow direction regardless of humidification level at the cathode side. This decreasing distribution of oxygen concentration is thought to result from continuous water formation by oxygen and hydrogen consumption by electrochemical reaction. 
Figure 6. Model water concentration on center of flow channel at different cathode relative humidities.

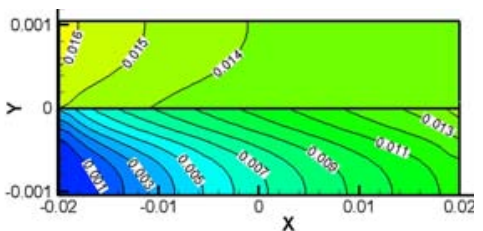

Cathode Humidification 0\%

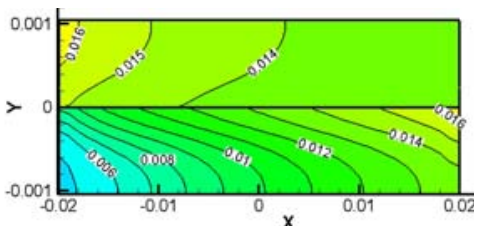

Cathode Humidification 30\%

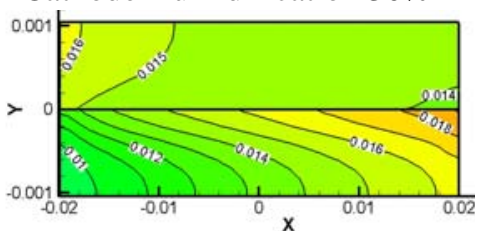

Cathode Humidification 60\%

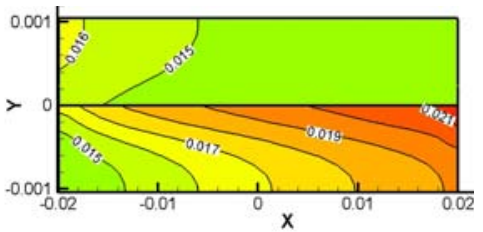

Cathode Humidification 90\%

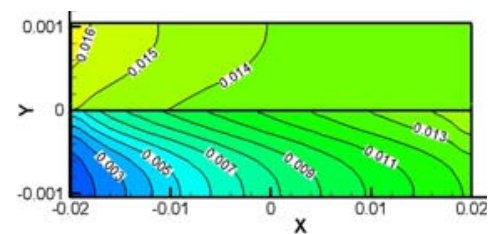

Cathode Humidification 10\%

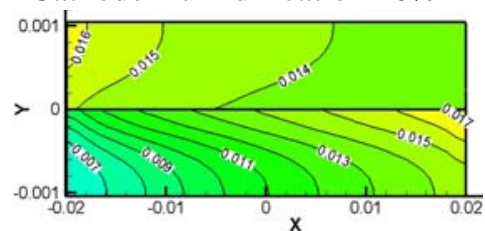

Cathode Humidification 40\%

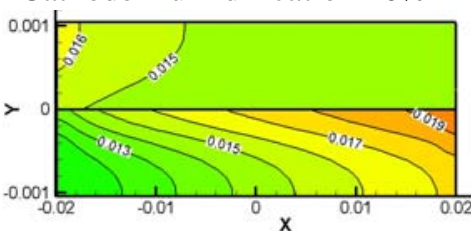

Cathode Humidification 70\%

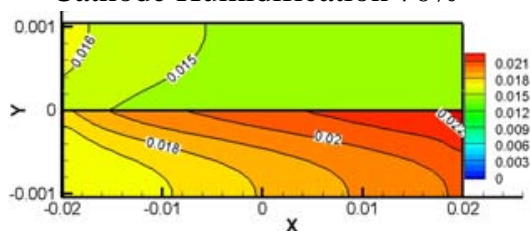

Cathode Humidification 100\%

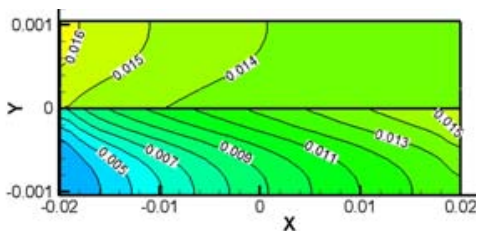

Cathode Humidification 20\%

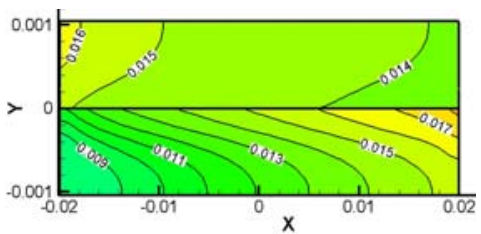

Cathode Humidification 50\%

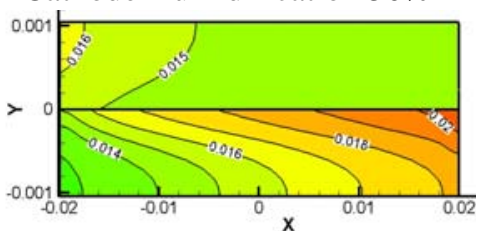

Cathode Humidification $80 \%$

Figure 7. Model oxygen concentration on center of flow channel at different cathode relative humidities.

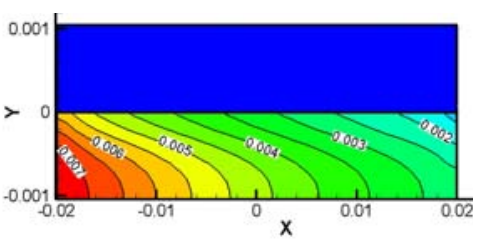

Cathode Humidification $0 \%$

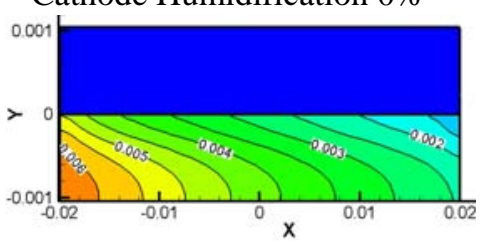

Cathode Humidification 30\%

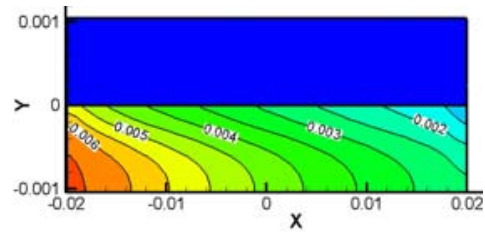

Cathode Humidification 10\%

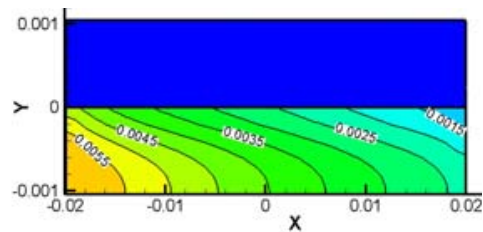

Cathode Humidification 40\%

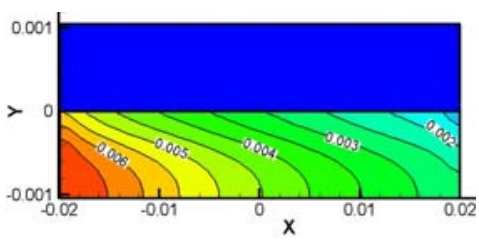

Cathode Humidification 20\%

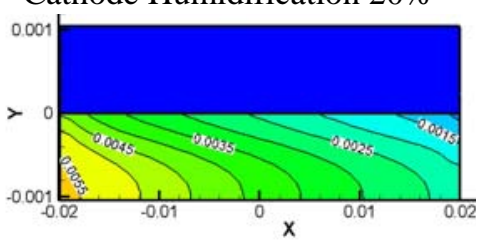

Cathode Humidification 50\% 
Figure 7. Cont.

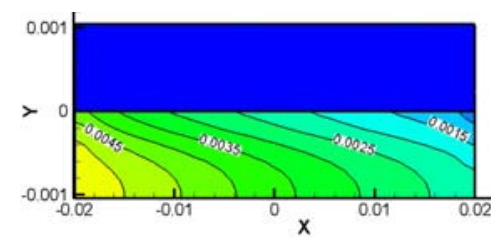

Cathode Humidification 60\%

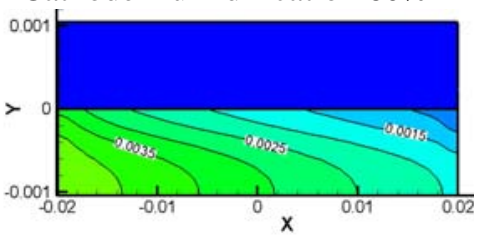

Cathode Humidification 90\%

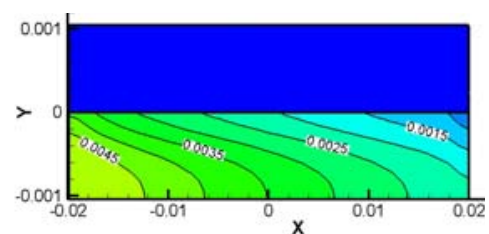

Cathode Humidification 70\%

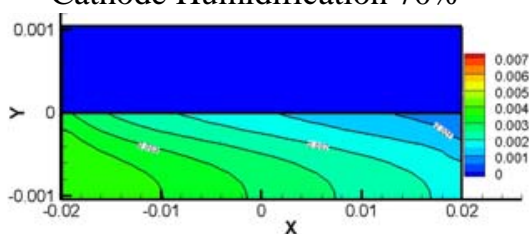

Cathode Humidification 100\%

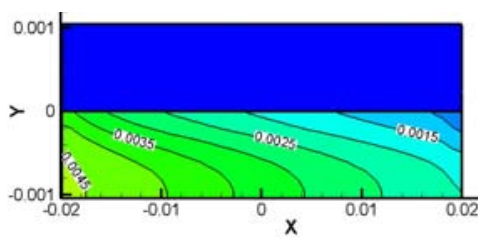

Cathode Humidification 80\%

Figures 8-10 show comparisons of the distribution of oxygen and water concentration on the gas diffusion layer at different humidity levels at the cathode channel. Figure 8 shows the distribution of water concentration on the gas diffusion layer at the anode side. Figure 9 and 10 show the distribution of water and oxygen concentration on the gas diffusion layer at the cathode side.

From comparisons for the distribution of water concentration in the gas diffusion layer at the anode side shown in Figure 8, the water concentration remains high at the flow channel inlet. The change in water concentration at the inlet and outlet of the flow channel with $0-30 \%$ of relative humidity at cathode was greater than that with $40 \%-100 \%$ of relative humidity at the cathode side. In addition, the distribution of water was constant, except for the inlet zone of the micro parallel flow channel in the gas diffusion layer at the anode side for case of $60 \%-100 \%$ of relative humidity at the cathode side.

Figure 9 shows comparisons of the distribution of water concentration in the gas diffusion layer at the cathode side. The distribution of water concentration also increased together with an increasing region of relative humidity at the cathode side. Water concentration at outlet of the flow channel increased more than water concentration at the inlet.

Figure 10 presents the comparisons of the distribution of oxygen concentration in the gas diffusion layer at the cathode side. The distribution of water concentration was opposite to the distribution of water concentration shown in Figure 10. As the humidity was increased and water concentration became greater, the proportion of oxygen and nitrogen decreased since the mixture ratio of water, oxygen and nitrogen is provided at a fixed value at the inlet of the flow channel. 
Figure 8. Model water concentration on anode side GDL at different cathode relative humidities.

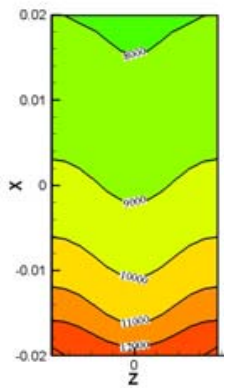

Cathode

Humidity $0 \%$

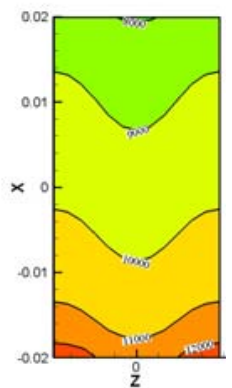

Cathode

Humidity $60 \%$

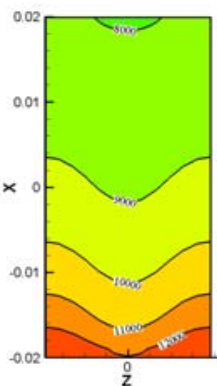

Cathode

Humidity $10 \%$

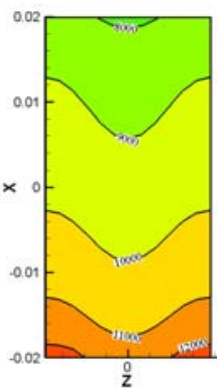

Cathode

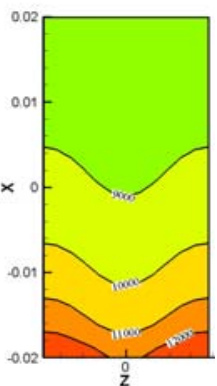

Cathode

Humidity 20\%

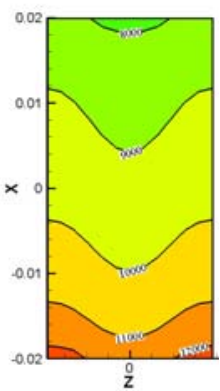

Cathode

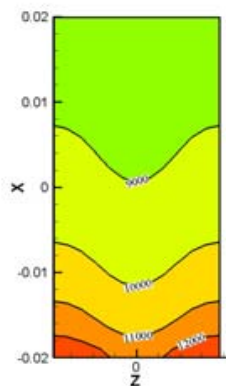

Cathode

Humidity 30\%

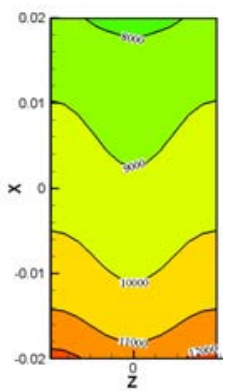

Cathode

Humidity 90\%

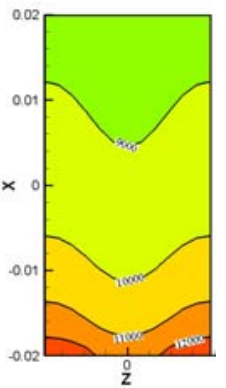

Cathode

Humidity 40\%

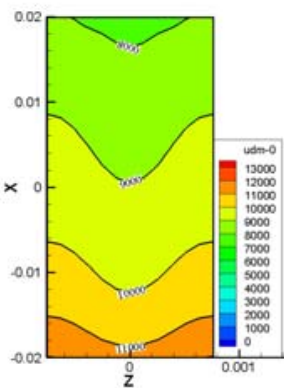

Cathode

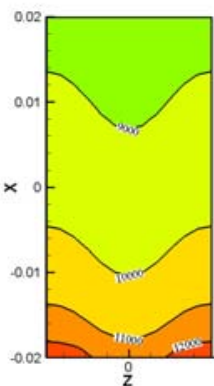

Cathode

Humidity $70 \%$

Humidity 100\%

Figure 9. Model water concentration on cathode side GDL at different cathode relative humidities.

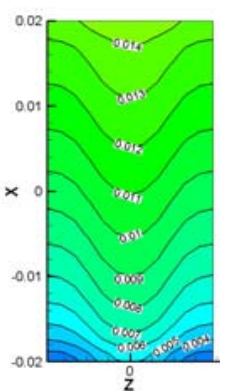

Cathode

Humidity $0 \%$

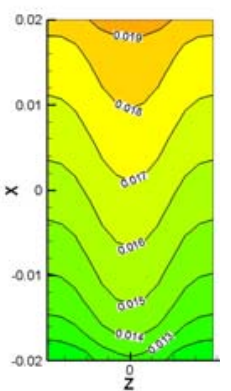

Cathode

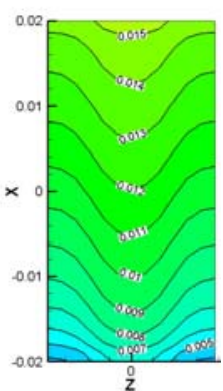

Cathode Humidity 10\%

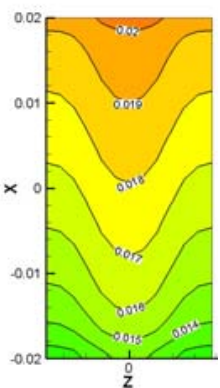

Cathode

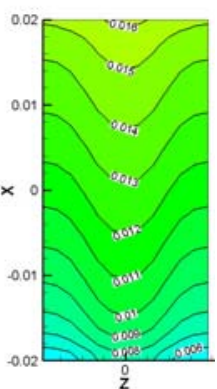

Cathode

Humidity 20\%

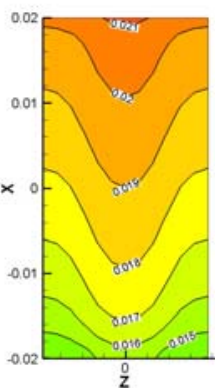

Cathode

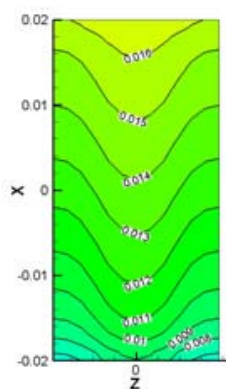

Cathode

Humidity 30\%

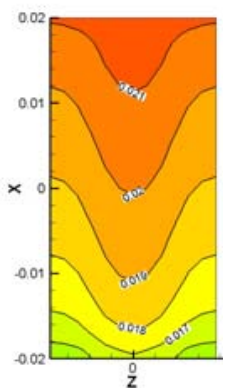

Cathode

Humidity 90\%

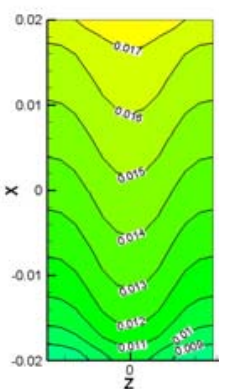

Cathode

Humidity 40\%

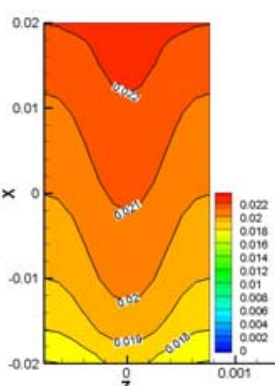

Cathode

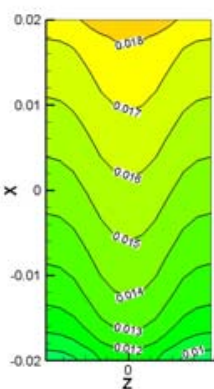

Cathode

Humidity 100\% 
Figure 10. Model oxygen concentration on cathode side GDL at different cathode relative humidities.

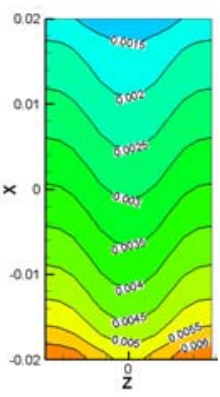

Cathode

Humidity 0\%

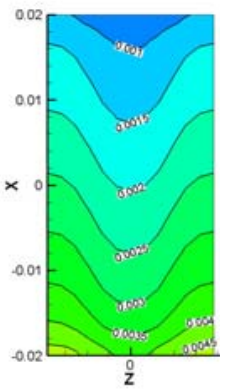

Cathode

Humidity $60 \%$

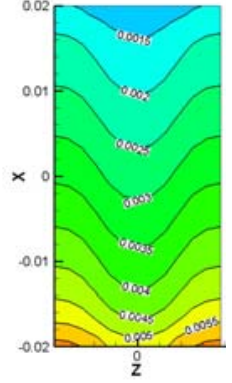

Cathode

Humidity $10 \%$

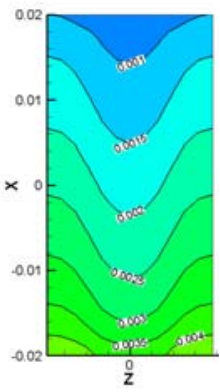

Cathode

Humidity $70 \%$

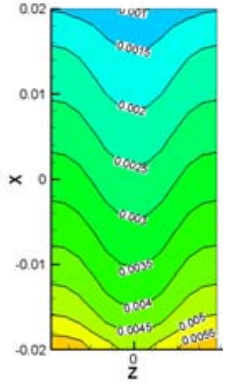

Cathode

Humidity 20\%

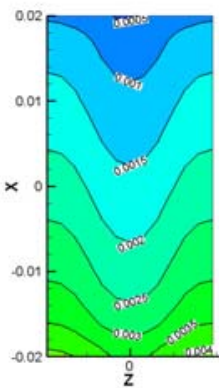

Cathode

Humidity $80 \%$

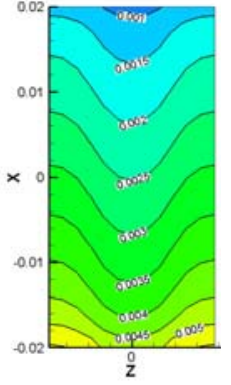

Cathode

Humidity 30\%

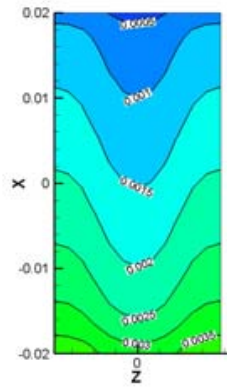

Cathode

Humidity 90\%

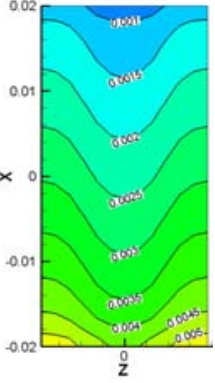

Cathode

Humidity 40\%

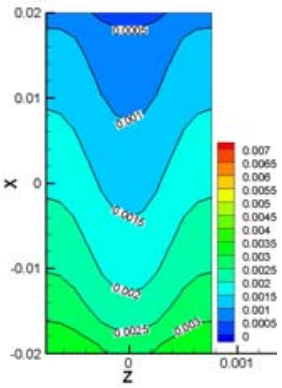

Cathode

Humidity 100\%

Figures 11 and 12 show the water transport from the electro-osmotic drag flux and back diffusion flux. It is known that the electro-osmotic drag, which transports water molecules through the polymer membrane with hydrogen ions, moves the water molecule from the anode side to the cathode side. Water formation at the cathode resulted in a gradient in the water content between the cathode side and anode side of the membrane. This gradient caused a water flux back to anode side which was superimposed to the electro-osmotic flux.

Figure 11 shows comparisons of the electro-osmotic drag flux at different humidity levels at the cathode side. A high region of electro-osmotic drag flux was distributed at the inlet of the micro parallel flow channel, which gradually decreased along to the outlet of the flow channel. The higher relative humidity at the anode side was, the higher the electro-osmotic drag flux became at the inlet of micro parallel flow channel. Also, electro-osmotic drag flux is generated much in $50-100 \%$ of relative humidity at the cathode side at the outlet of flow channel.

Figure 12 presents the back diffusion flux at various humidity levels at the cathode side and shows that the back diffusion flux at the inlet of the flow channel was low compared to the electro-osmotic drag flux. The back diffusion flux greatly increased along to the outlet of the flow channel. The back diffusion flux remained almost constant in the region except for the inlet in the flow channel for $60 \%-100 \%$ of relative humidity at the cathode side. 
Figure 11. Electro-osmotic drag on the membrane at different cathode relative humidities.

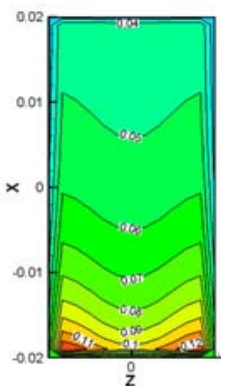

Cathode

Humidity $0 \%$

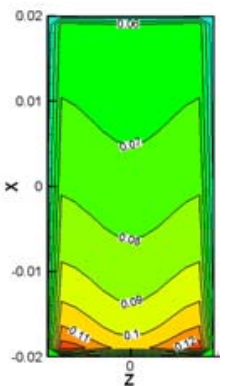

Cathode

Humidity $60 \%$

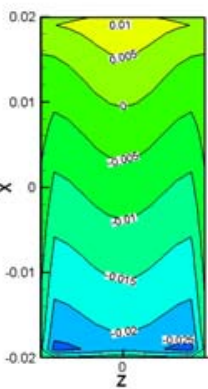

Cathode

Humidity $0 \%$

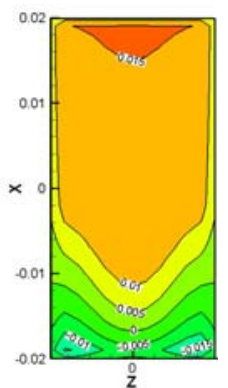

Cathode

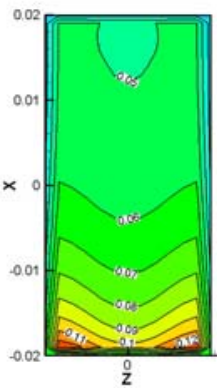

Cathode

Humidity $10 \%$

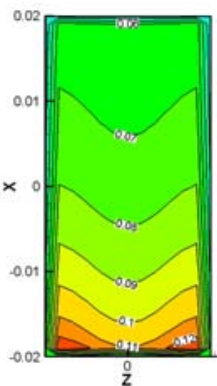

Cathode

Humidity 70\%

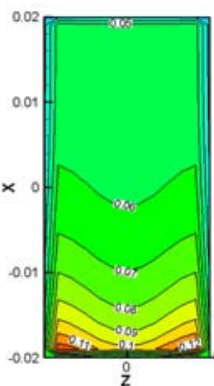

Cathode

Humidity 20\%

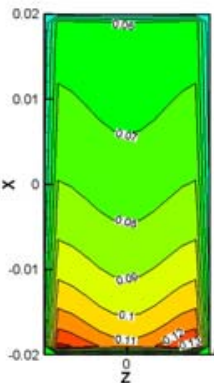

Cathode

Humidity $80 \%$

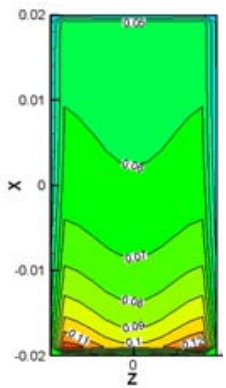

Cathode

Humidity 30\%

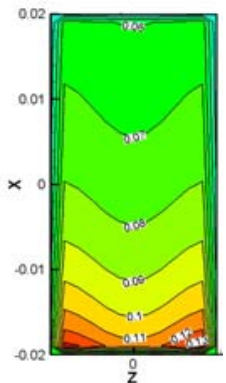

Cathode

Humidity $90 \%$

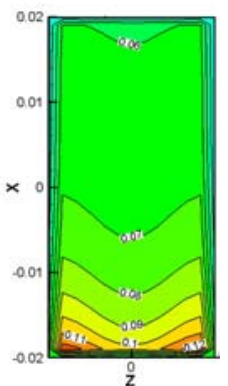

Cathode

Humidity 40\%

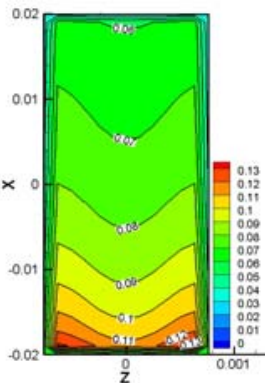

Cathode

Humidity 100\%

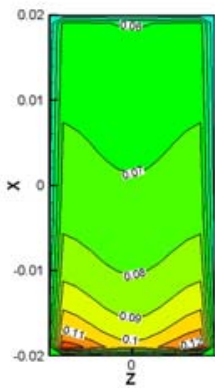

Cathode

Humidity 50\%

Figure 12. Back diffusion drag force.

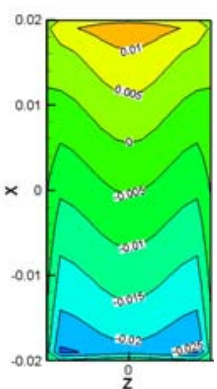

Cathode

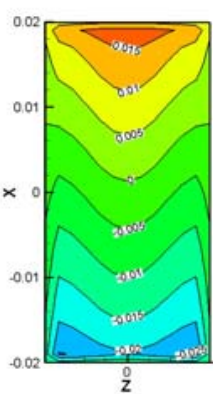

Cathode

Humidity $20 \%$

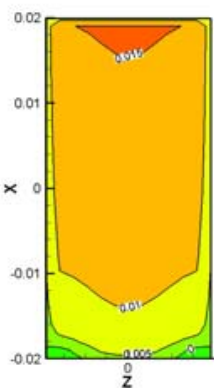

Cathode

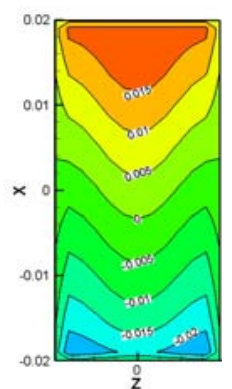

Cathode

Humidity 30\%

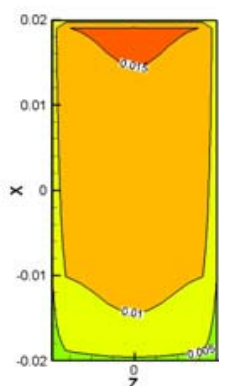

Cathode

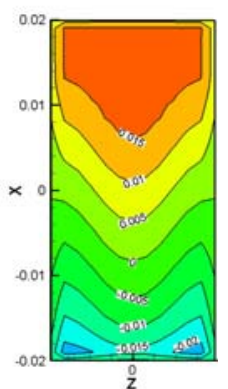

Cathode

Humidity 40\%

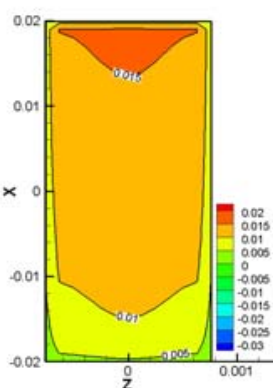

Cathode

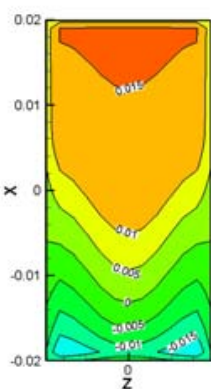

Cathode

Humidity 50\%

Humidity 60\%

Humidity $70 \%$

Humidity $80 \%$

Humidity 90\%

Humidity 100\% 
Figure 13 shows the ion conductivity in the membrane from variations in the different relative humidity at the cathode side. The ion conductivity of the membrane increased as the relative humidity at the cathode side increased. A region of high ion conductivity is formed at the inlet of the micro parallel flow channel, where the electro-osmotic drag flux is high. The lowest ion conductivity in the membrane was shown for the case of $0 \%$ of relative humidity at the cathode side, whereas the highest ion conduction was found in case of $100 \%$ of relative humidity at the cathode side.

Figure 13. Membrane ion conductivity at different cathode relative humidities.

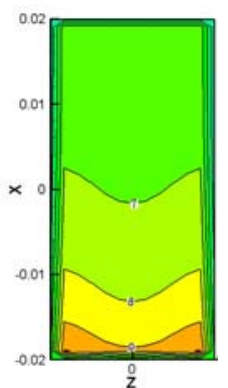

Cathode Humidity $0 \%$

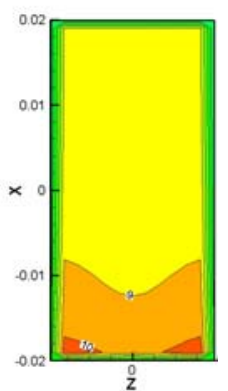

Cathode

Humidity $60 \%$

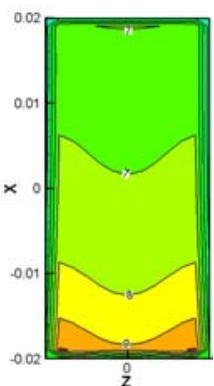

Cathode Humidity $10 \%$

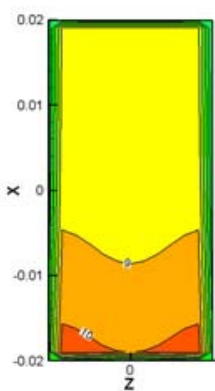

Cathode

Humidity 70\%

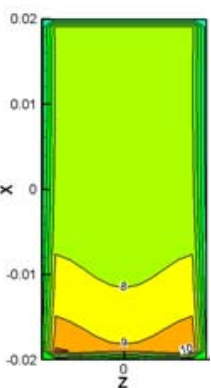

Cathode

Humidity 20\%

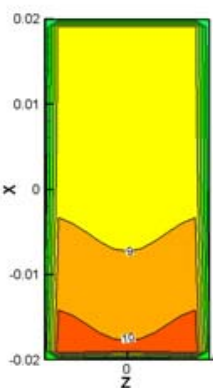

Cathode

Humidity $80 \%$

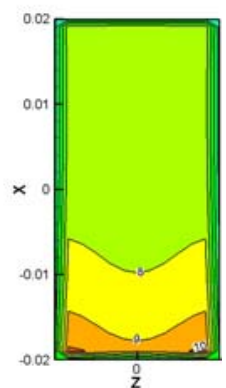

Cathode

Humidity 30\%

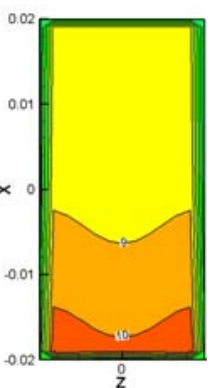

Cathode

Humidity 90\%

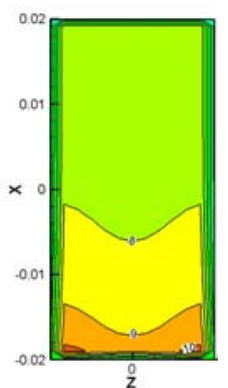

Cathode

Humidity $40 \%$

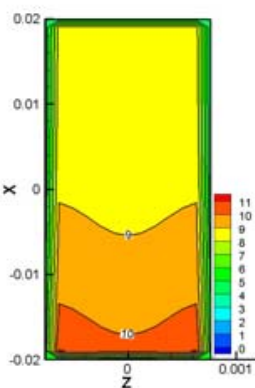

Cathode

Humidity 100\%

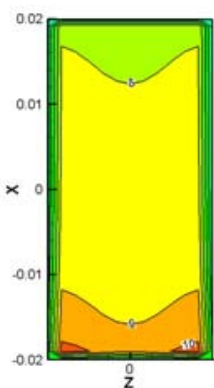

Cathode

Humidity 50\%

Figure 14 depicts the local current density at different relative humidity levels at the cathode side. The local current density was relatively high at the inlet of flow channel and low at the outlet of flow channel under conditions of $0-30 \%$ of low humidity at the cathode side. The entire area of the reaction had the constant level of local current density for the case of $40 \%-70 \%$ of humidity at the cathode side. However, the local current density was shown to be low for the case of $80 \%-100 \%$ relative humidity at the cathode side.

Figure 15 presents ion conductivity and model oxygen concentration at different cathode relative humidity cathode. It is confirmed that membrane ion conductivity was increased with increasing relative humidity at the cathode relative humidity and model oxygen concentration at the cathode is found to be increased with decreasing relative humidity. 
Figure 14. Local current density at different cathode relative humidities.

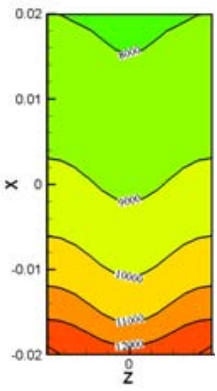

Cathode

Humidity $0 \%$

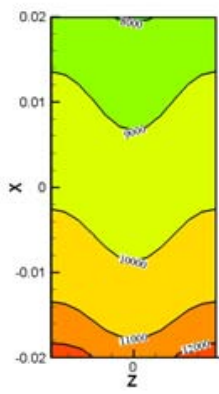

Cathode

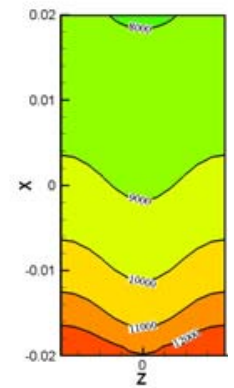

Cathode

Humidity 10\%

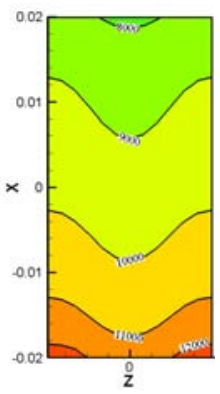

Cathode

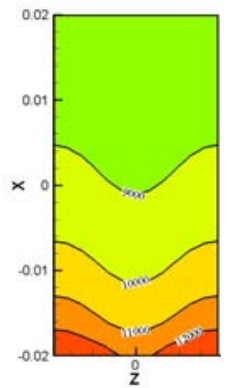

Cathode

Humidity 20\%

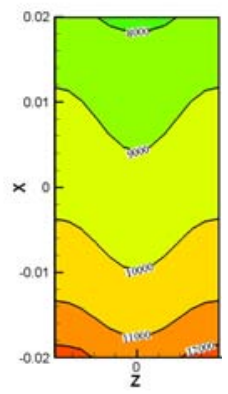

Cathode

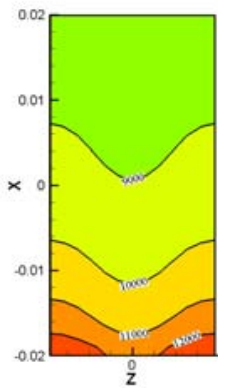

Cathode

Humidity 30\%

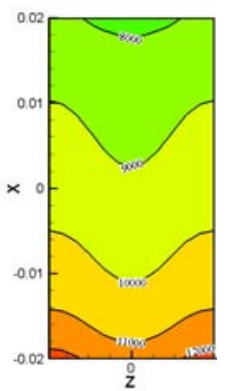

Cathode

Humidity 90\%

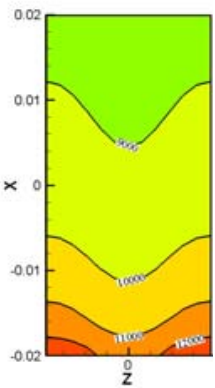

Cathode

Humidity 40\%

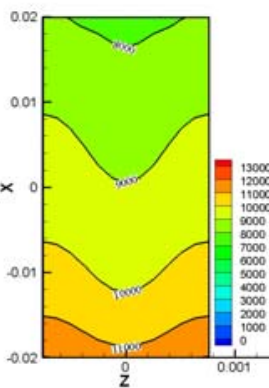

Cathode

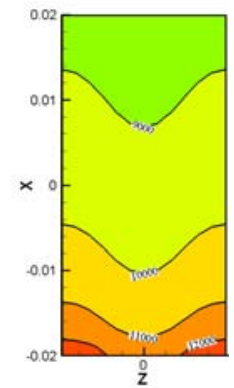

Cathode

Humidity 50\%

Humidity 100\%

Figure 15. Comparison of ion conductivity and moral oxygen concentration at different cathode relative humidities.

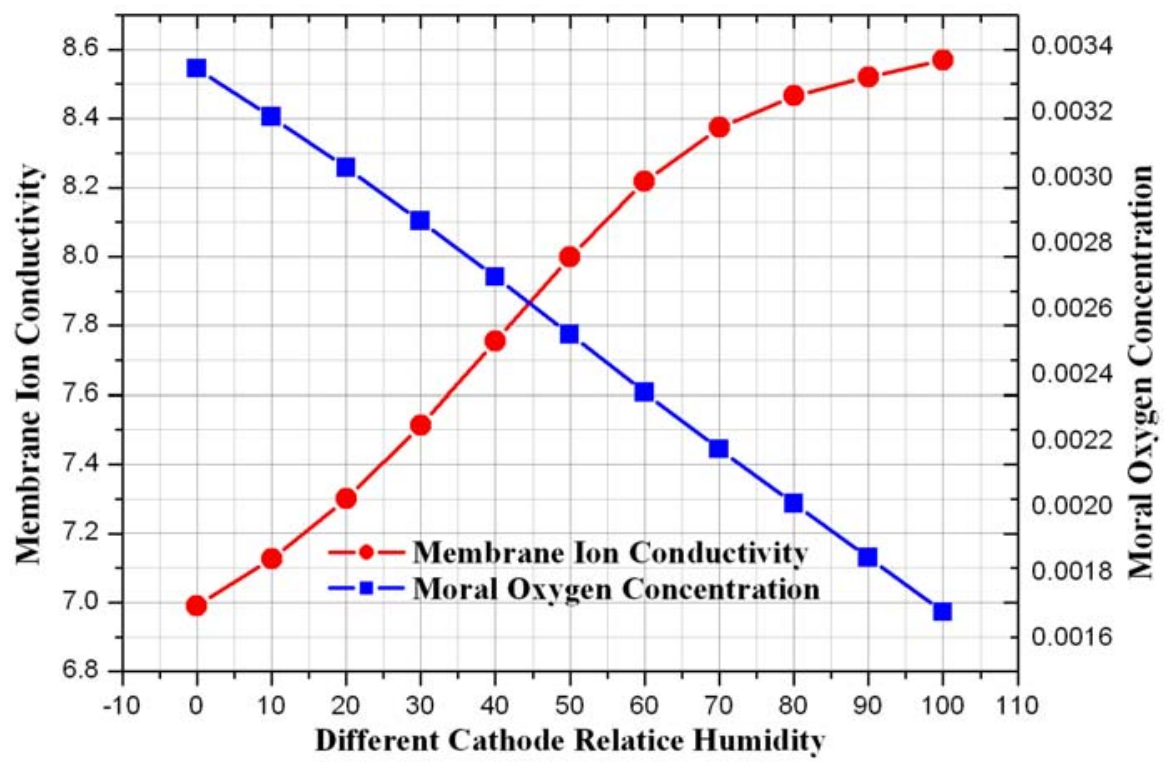

Figure 16 shows the average current density at the different relative humidity levels at the cathode side. The highest average current density is noticeable at $100 \%$ humidity at the anode side and at $60 \%$ humidity at the cathode side. Although the hydrogen ions can smoothly move from the anode side to the cathode side due to high ion conductivity in the membrane from $100 \%$ humidity at anode and cathode relative humidity, the performance of the fuel cell was not expected to be best because of the 
increased water concentration at cathode side resulting in the decreased oxygen concentration at cathode side. Therefore, to make a fuel cell with the best performance, there is trade-off between performance gain by increase of high ion conductivity due to high humidity and performance loss by reduction of oxygen due to high water concentration by electro osmotic drag and back diffusion in order to make best performance of fuel cell.

Figure 16. Average current density at different cathode relative humidities.

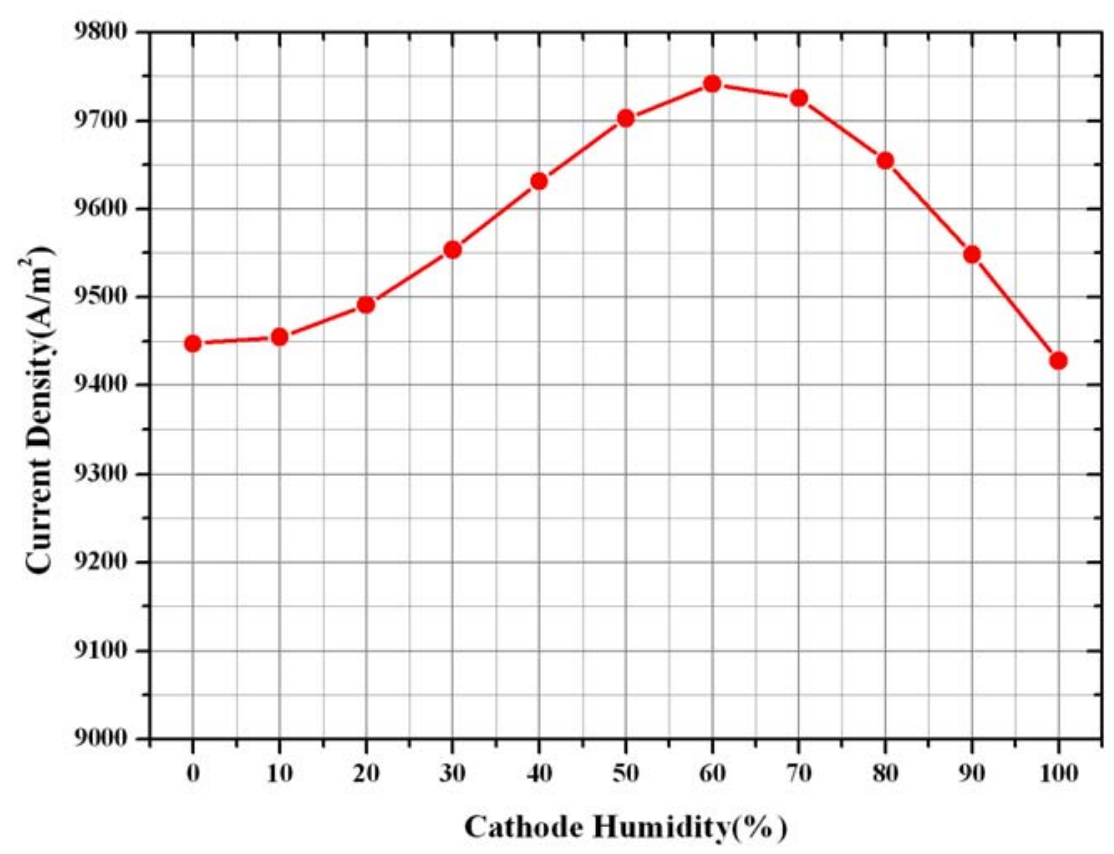

\section{Conclusions}

By using a fully three dimensional simulation model for a PEM fuel cell that can deal with anode and cathode flow together, the following conclusions could be obtained for a PEM fuel cell with micro parallel channelsa:

(1) The computed polarization curve is in good agreement with the experimental polarization curve at low and moderate current density. At high current density, the effects of two phase flow should be considered.

(2) The oxygen and water concentration on the centerline surface of the micro parallel channel and gas diffusion layer under different relative humidity at cathode side was changed greatly due to electrochemical reaction and electro osmotic drag and back diffusion.

(3) The highest average current density was noticeable at $100 \%$ humidity at the anode side and at $60 \%$ humidity at the cathode side. Although the hydrogen ion can smoothly move from the anode side to the cathode side due to high ion conductivity in the membrane from $100 \%$ humidity at anode and the cathode relative humidity, the performance of fuel cell was not expected to be best because of the increased water concentration at cathode side resulting to the decreased oxygen concentration at cathode side.

(4) It is found that there is trade-off between performance gain by increase of high ion conductivity due to high humidity and performance loss by reduction of oxygen due to high water 
concentration by electro osmotic drag and back diffusion in order to make best performance of fuel cell.

\section{References and Notes}

1. Kazim, A.; Liu, H.T.; Forges, P. Modeling of performance of PEM fuel cells with conventional and interdigitated flow fields. J. Appl. Electrochem. 1999, 29, 1409-1416.

2. Nguyen, T.V. Modeling two-phase flow in the porous electrodes of proton exchange membrane fuel cells using the interdigitated flow fields. In Proceedings of the 195th Meeting of Electrochemical Society, Seattle, WA, USA, May 1999, p. 4-7.

3. Wood, D.L.; Yi, J.S.; Nguyen, T.V. Effect of direct liquid water injection and interdigitated flow field on the performance of proton exchange membrane fuel cells. Electrochem. Acta 1998, 43, 3795-3809.

4. Lee, P.H.; Cho, S.A.; Han, S.S.; Hwang, S.S. Performance characteristics of proton exchange membrane fuel cell(PEMFC) with interdigitated flow channel. Int. J. Automot. Technol. 2007, 8, 761-769.

5. Wang, D.X.; Duan, Y.Y.; Yan, W.M.; Weng, F.B. Effect of humidity of reactants on the cell performance of PEM fuel cells with parallel and interdigitated flow field designs. J. Power Soc. 2008, 176, 247-258.

6. Saleh, M.M.; Okajima, T.; Hayase, M.; Kitamura, F.; Ohsaka, T. Exploring the effects of symmetrical and asymmetrical relative humidity on the performance of $\mathrm{H}_{2}$ /air PEM fuel cell at different temperatures. J. Power Soc. 2007, 164, 503-509.

7. Um, S. Computational modeling of transport and electrochemical reaction in proton exchange membrane fuel cell. Ph.D. Thesis, Penn State University: Pennsylvania, USA, 2003.

8. Lee, W.K.; van Zee, J.W.; Shimpalee, S.; Dutta, S. Effect of humidity on PEM fuel cell performance part I: Experiments. In Proceedings of International Mechanical Engineering Congress \& Exposition, Nashville, TN, USA, November 14, 1999.

9. Shimpalee, S.; Dutta S.; Lee, W.K.; van Zee, J.W. Effect of humidity on PEM fuel cell performance part II-Mumerical simulation. In Proceedings of ASME IMECH, Nashville, TN, USA, 1999; HTD 364-1, pp. 367-374.

10. Lee, W.K.; Ho, C.H.; van Zee, J.W.; Murthy, M. The effects of compression and gas diffusion layers on the performance of a PEM fuel cell. J. Power Soc. 1999, 84, 45-51.

11. Shimpalee, S.; Dutta S.; van Zee, J.W. Numerical prediction of local temperature and current density in a PEM fuel cell. In 2000IMECE, Session on Transport Phenomena in Fuel Cell Systems, Orlando, FL, USA, 2000, paper no, 2-6-3-2.

12. Dutta, S.; Shimpalee, S.; van Zee, J.W. Numerical prediction of mass-exchange between anode and cathode channels in a PEM fuel cell, Int. J. Heat Mass Transfer 2001, 44, 2029-2042.

13. Springer, T.; Zawodzinski, T.; Gottesfeld, S. Polymer electrolyte fuel cell model. J. Electrochem. Soc. 1991, 138, 2334-2342.

14. Ticianelli, E.A.; Derouin, C.R.; Srinivasan, S.J. Localization of platinum in low catalyst loading electrodes to to attain high power densities in SPE fuel cells. J. Electroanal. Chem. 1988, 251, 275-295. 
15. Um, S.K.; Wang, C.Y.; Chen, K.S. Computational Fluid Dynamics Modeling of Proton Exchange Membrane Fuel Cells. J. Electrochem. Soc. 2000, 147, 4485-4493.

(C) 2009 by the authors; licensee Molecular Diversity Preservation International, Basel, Switzerland. This article is an open-access article distributed under the terms and conditions of the Creative Commons Attribution license (http://creativecommons.org/licenses/by/3.0/). 